\title{
Tiroid kanserinde moleküler etyolojik faktörler
}

\author{
The molecular etiological parameters in thyroid cancer \\ Semra Özdemir*, Öztürk Özdemir
}

Nükleer Tıp Anabilim Dalı (Yrd. Doç. Dr. S. Özdemir), Tıbbi Genetik Anabilim Dalı (Prof. Dr. Ö. Özdemir) Çanakkale Onsekiz Mart Üniversitesi Tıp Fakültesi, TR-17100 Çanakkale

\section{Özet}

Tiroid kanseri en sık görülen endokrin kanserdir ve dünya çapında sıklığı giderek artmaktadır. Son zamanlardaki moleküler teknolojik çalışmalar, tiroid kanser tanı ve tedavisinin doğru yapılabilmesi için etyolojik parameterlere yoğunlaşmış durumdadır. Şimdiye kadar bu konuda üzerinde çalışılmış birçok moleküler ve immünohistokimyasal parametre bildirilmiştir. Son literatür bilgileri, tiroid kanseri ile genetik parametreler arasında güçlü bir ilişkinin olduğunu ortaya koymuştur. Normal tiroid dokusunda kanser tetiklenmesi ve ilerlemesi, nokta mutasyonlar, translokasyonlar, kromozomlararası yeniden düzenlemeler (rearrangements), aktif proto-onkogen ve inaktif tümör baskılayıcı gen şeklinde meydana gelen epigenetik alterasyonlar gibi çoklu genetik ve epigenetik değişikliklerle gerçekleşmektedir. Yine son rapor edilen literatür bilgileri, proto-onkogenlerin fonksiyon kazanarak ve tümör süpresör genlerin ise fonsiyon kaybederek tiroid kanserlerinin tetiklenmesinde ve/veya ilerlemesinde görev yapmaları bu gen ailelerinin karsinogenezisde antagonistik bir etkiye sahip olduklarını göstermektedir. Tiroid doku tümörleri ve nodüllerinin, moleküler genetik belirteçler açısından (somatik, germ-line) kimliklendirilmesinin malign-benign doku ayırt edilmesinde, kesin tanı ve etkin tedaviçin hayati öneme sahiptir. Her bir kanser olgusunda özgün moleküler genetik değişikliklerin neler olduğu öncelikle tespit edilmelidir. Ancak bu durumda kanser subtiplemesi doğru yapılabilir ve bu doğrultuda hastanın doğru ve etkin tedavi alması sağlanabilir. İlgili nodül ve tümör dokusunun neden kanserleştiğinin ipuçlarını yine içinde barındırmaktadır, bu moleküler etyolojik sebeplerin doğru tespiti tiroid kanserlerinin tedavisi için yeni ve etkin tedavi stratejilerinin geliştirilmesine olanak sağlar. Bu derleme makalesinde son literatür bilgileri 1şığında tiroid kanserlerinde doğrudan ve/veya aracılık eden moleküler genetik paremetreler ve etki mekanizmaları olabildiğince geniş bir spektrumda ele alınmıştır.

Anahtar sözcükler: Tiroid kanseri, tanı, prognoz, moleküler belirteçler

\begin{abstract}
Thyroid cancer is a common endocrine malignancy its prevelance is increasing worldwide. Currently, the application of molecular technologies has focused on etiological parameters for the accurate diagnosis and therapy of thyroid cancer. Until now in this issue many molecular and immunohistochemical parameters have been reported. Recent literature show that strong association between genetic parameters and thyroid cancer. Initiation and progression of thyroid cancers arise as the consequence of multiple genetic and epigenetic alterations such as; structural point mutations, chromosomal rearrangements and epigenetic events that activate proto-oncogenes and inactivate tumor suppressor genes. There are lots of various tumor-suppressor genes are epigenetically silenced in thyroid cancers. Gain-of-function for proto-oncogenes and loss-offunction for tumour supressor genes have a crucial role in the initiation and/or progression of the thyroid carcinogenesis. The determining of somatic and/or germline molecular alterations have been recognized as helpful diagnostic and prognostic markers and valuable tools for the management of tumoural/nontumuoral nodules in thyroid cancer patients. Known details about those molecular etiological parameters provide further research and clinical development targets, novel diagnostic and therapeutic strategies for thyroid cancers treatment. Current article reviews the molecular etiological alterations in thyroid cancer that help identify relevant biologic pathways to drive cancer development. Direct and undirect moleculer ethiological parametes and action mechanisims that play crucial role in the thyroid cancers widely reviewed in the currenr report.
\end{abstract}

Keywords: Thyroid cancer, diagnosis, prognosis, molecular markers 
Geliş tarihi/Received: 18 Aralık 2013; Kabul tarihi/Accepted: 13 Ocak 2014

\author{
*İletişim adresi: \\ Dr. Semra Özdemir, Nükleer Tıp Anabilim Dalı, Çanakkale Onsekiz Mart Üniversitesi Tıp \\ Fakültesi, TR-17100 Çanakkale. E-posta: semozdemir@yahoo.com
}

\title{
Giriş
}

Tiroid bezi insanda en büyük endokrin bez olup histolojk olarak folliküler ve parafolliküler $\mathrm{C}$ hücrelerini içerir. En s1k görülen endokrin malignite tipi olan tiroid kanserleri de bu iki hücre tipinden köken alırlar. Tiroid kanserlerinin tüm kanser tipleri arasında görülme sıklığı \%1 civarında olmakla birlikte çalışmalar, son yıllarda görülme sıklığında belirgin bir artış olduğunu göstermektedir. Kadın/erkek oranı 3/1 ve görülme yaşı 20-60 yaş arası iken özellikle kadınlarda ve gençlerde görülme sıklı̆̆ının giderek arttığı bildirilmektedir [1-3]. Folliküler hücrelerden köken alan kanserler iyi diferansiye (papiller ve foliküler), zayif diferansiye (insular) ve undiferansiye tip (anaplastik) olmak üzere üç ana grupta toplanır. Folliküler hücrelerden köken alan kanserlerin en sık görülen tipi, iyi diferansiye papiller ve folliküler karsinomalardır. Parafolliküler C hücrelerinden köken alan kanser tipi ise medüller karsinomadır. Yaygın tiroid doku kanserleri sırasıyla, \%90'1 iyi diferansiye, \%5-9'u medüller, \%1-2 anaplastik, \%1-3'u lenfoma ve diğer nadir tümörlerden oluşmaktadır. İyi diferansiye tiroid karsinomlarının dağılımı ise \%80-85 papiller, \%10-15 follikuler, \%3-5 hürtle hücreli veya onkositik karsinomlar şeklindedir [4].

Tiroid follikül hücrelerinin büyüme ve çoğalma yetenekleri vardır. Tiroid hücrelerinin büyüme ve fonksiyonlarını uyaran en önemli faktör tiroid stimülan hormonudur (TSH). Vücuttaki diğer hücrelerde olduğu gibi tiroid hücrelerinin yaşam döngüsü de hücre bölünmesi, farklılaşması ve ölümü (apoptozis) olmak üzere 3 aşamalıdır [5]. Bu hücre yaşam döngüsünü yönlendiren bazı proteinler proto-onkogenler, tümör supresör genler ve mutator genler tarafindan kodlanırlar. $\mathrm{Bu}$ nedenle bu genlerde oluşan çeşitli fonksiyon aksamaları hücre yaşam döngüsündeki aşamalarda oluşan problemler nedeniyle kanserleşme sürecine gidebilmektedir [6]. Tiroid kanserlerinin etyolojisinde radyasyona maruziyet dışında saptanabilmiş kesin çevresel faktörlerden bahsedilememektedir [7]. Endemik iyot eksikliği bölgelerinde folliküler kanserin, iyot proflaksisi uygulanan bölgelerde ise papiller kanserin daha sık görüldügünü bildiren yayınlar bulunmakla birlikte iyot eksikliği ya da fazlalığı kesin etyolojik faktör olarak suçlanamamaktadır. Yine hashimato tiroiditi ve graves hastalığında tiroid kanser riskinin arttı̆̆ına dair yayınlar mevcuttur [8]. Tiroid kanserlerinin moleküler etyolojik faktörleri ise son zamanlarda giderek aydınlatılmakta, bu konuda çok sayıda araştırma yapılmaktadır. Bu konudaki gelişmeler tiroid kanserlerinin hem tanı, hem tedavi aşamasında yeni bakış açıları gelişmesine neden olmaktadır. Tiroid kanserlerinin tanı aşamasında güvenirliliğgi en yüksek yöntem olarak kabul edilen ince iğne aspirasyon biopsisinde (İİB) bile \%1020 oranında kesin tanıya gidilememekte şüpheli sonuçlar rapor edilmektedir. Şüpheli (indeterminate) olarak tanımlanan nodüllere cerrahi uygulandığında da dörtte üçü benign nodül çıkmaktadır [9]. $\mathrm{Bu}$ nedenle patolojik tanıların moleküler belirteçlerle desteklenmesi artık kaçınılmaz olmaya başlamıştır. Doku tanılarının, genetik tanılarla güçlendirilmesi kanser tanısının güvenirliliğini artıracak ve doğru teşhis-tedavi süreci daha sağlıklı işleyecektir. Son literatür bilgileri göstermiştir ki aynı kanser tipi ve aynı histopatolojik doku tanısı almalarına rağmen her bireyde farklı genetik etyolojik nedenler söz konusu olabilmektedir. Dolayısıyla kanser dokularının histopatolojik tanımlanmaları dışında genetik kimliklendirmelerinin yapılması, daha doğru ve bireye özgü tedavi için artık zorunlu hal almıştır. Bu nedenle bu makalede tiroid kanserlerinde önemli moleküler etyolojik sebepler olabildiğince geniş bir perspektif içinde ele alındı ve son literatür bilgileriyle tartışıldı. 
Tüm kanserlerde olduğu gibi tiroid kanser oluşumu da multifaktöriyel ve poligenetik bir süreçtir ve etyopatogenezi araştırılırken tek bir faktörden ya da genden bahsetmek mümkün değildir. Yapılan araştırmalar onkogenez için tek bir genetik değişimin yeterli olmadığını, tümör supresör genler, proto-onkogenler ve yapısal genlerde bir dizi mutasyonun oluşması gerektiğini göstermiştir. Yani kanser gelişimi, genetik açıdan çok aşamalı bir süreçtir. Bu süreç sırasında oluşan mutasyonlar kendiliğinden ya da mutajenik etkilere bağlı olarak gelişebilir [10].

$\mathrm{Bu}$ çok faktörlü ve çok aşamalı sürecin etyolojik parametre ve belirteçlerini üçe ayırarak inceleyecek olursak;
A. İmmünohistokimyasal belirteçler,
B. Moleküler genetik belirteçler,
C. Hücre büyümesini indükleyen ya da inhibe eden belirteçler olarak siniflandirabiliriz.

\section{A. İmmünohistokimyasal belirteçler}

A.1. Galektin-3 (Gal-3): Galektinler hücre büyümesi, aktivasyonu, neoplastik transformasyon, metastaz gelişimi, apoptozis, hücre-hücre ve hücre-ekstrasellüler matriks etkileşimlerinde rol oynayan bir protein ailesidir. Galektin-3 $\beta$ galaktozidaz bağlayan spesifik bir proteindir. Kanser gelişimindeki rolü tam olarak bilinmemekle birlikte Gal-3 ün artmış ekspresyonunun tümör hücrelerinin adhezyon ve motilitelerini değiştirerek metastaz potansiyelini artırdıkları bildirilmektedir [11]. Birçok araştırma sonuçlarına göre Gal-3 özellikle papiller tiroid kanserlerinde olmak üzere differensiye tiroid kanserlerinde pozitiftir. Tiroid malignitelerinde Gal-3 yüksek duyarlılığa düşük özgüllüğe sahip bir markır olup Gal-3 varlığı maliginite olasılığını güçlendirmekle birlikte negatif olması maligniteyi ekarte ettirememektedir [12].

A.2. Hector battifora mesothelial cell antibody (HBME1): Mezotelyal hücrelerin mikrovilluslarında saptanan, antijeni bilinmeyen bir monoklonal antikordur. Hücre adezyonunda ve sinyalizasyonunda rolü olduğu düşünülmektedir. Follikül hücrelerinden kaynaklanan malign neoplazmlarda spesifik bir markırdır. Özellikle papiller tiroid karsinomunda güvenli pozitif sonuç verdiğinden tanısı zor papiller karsinomaların, hiperplazilerden ayırt edilmesinde yararlıdır [13, 14].

A.3. Sitokeratin 19 (CK-19): Sitokeratinler epitel hücrelerinin intermediyal filamentlerinden şekil alan ara filamanlardır ve asıl görevleri hücrelerin mekanik strese karşı koyabilmelerini sağlamaktır. İnsanlarda sitokeratinin 20 farklı izotipi bulunmakla birlikte tiroid karsinomalarıyla ilişkili olan tipi sitokeratin-19 dur. Hem tümoral olmayan tiroid follikül epitelini, hem papiller ve folliküler karsinoma epitel hücrelerini boyamaktadır. Diğer immünohistokimyasal markırlarla birlikte kullanılması spesifiteyi arttırmaktadır [15, 16].

A.4. Kalsitonin: Medüller tiroid kanserlerinde yüksek oranda ekspresyonu söz konusudur. Yüksek kalsitonin düzeyleri, medüller tiroid kanserleri için sensitif bir markır olmakla birlikte, spesifik değildir. Çünkü hiperparatiroidizm, renal yetmezlik ve nöroendokrin tümörler gibi bazı tiroid dışı patalojilerinde ve bazı ilaçların kulanımında da (omeprazol, glukokortikoidler, beta-blokerler, glukagon gibi) kalsitonin düzeylerinin yükselebildiği bilinmektedir [17, 18].

\section{B. Moleküler genetik belirteçler}

Tiroid kanserinde olası moleküler genetik etyolojik sebepleri, şu şekilde sınıflandırmak mümkündür:

1. Onkogen aracılı tiroid kanserleri

2. Tümör supresör gen arac1lı tiroid kanserleri

3. Fonksiyonel gen aracilı tiroid kanserleri

4. miRNA downregülasyona bağlı tiroid kanserleri 
B.1. Onkogen aracılı tiroid kanserleri: Yüksek canlılarda (eukaryotik genomda) 200 civarında onkogen tanımlanmıştır. Dominant kalıtım gösteren onkogenlerin fenotipte etkisinin ortaya çıkması için allellerden bir tanesinin mutasyona uğraması yeterlidir. Fonksiyonel bir hücrede istenmeyen onkogenik ürün üreten bu genler sağlıklı hücrelerde (wild) inaktiftirler. Fonksiyon yapmayan bu genler proto-onkogen olarak tanımlanırlar. İnsanda tümörogenezden primer olarak sorumlu oldukları varsayılan bu sessiz (inaktif) genlerin çeşitli hücre ve dokularda fonksiyon kazanmaları yani onkogene dönüşmeleri iki mekanizmayla gerçekleşir.

1. Mutasyonlar: Proto-onkogenler, genomik yapılarında değişiklik meydana geldiğinde aktif hale gelerek onkogene dönüşürler.

2. Epigenetik alterasyon: Epigenetik alterasyon, DNA dizisinde değişiklik olmadan gen ekspresyonunun değişikliğe uğraması durumudur. Sağlıklı bir hücrede protoonkogenlerin promotor gen alt birimleri hipermetile durumda olduğundan protein ekspresyonuna katılamazlar. Proto-onkogenler epigenetik alterasyon yoluyla promotor alt biriminde DNA hipometilasyonuna bağlı olarak aktifleşebilir ve hücrede transformasyonu başlatan onko-protein sentezine neden olurlar (Şekil 1). Yani metilasyon gen ekspresyonunun düzenlenmesinde rol oynamaktadır [19].

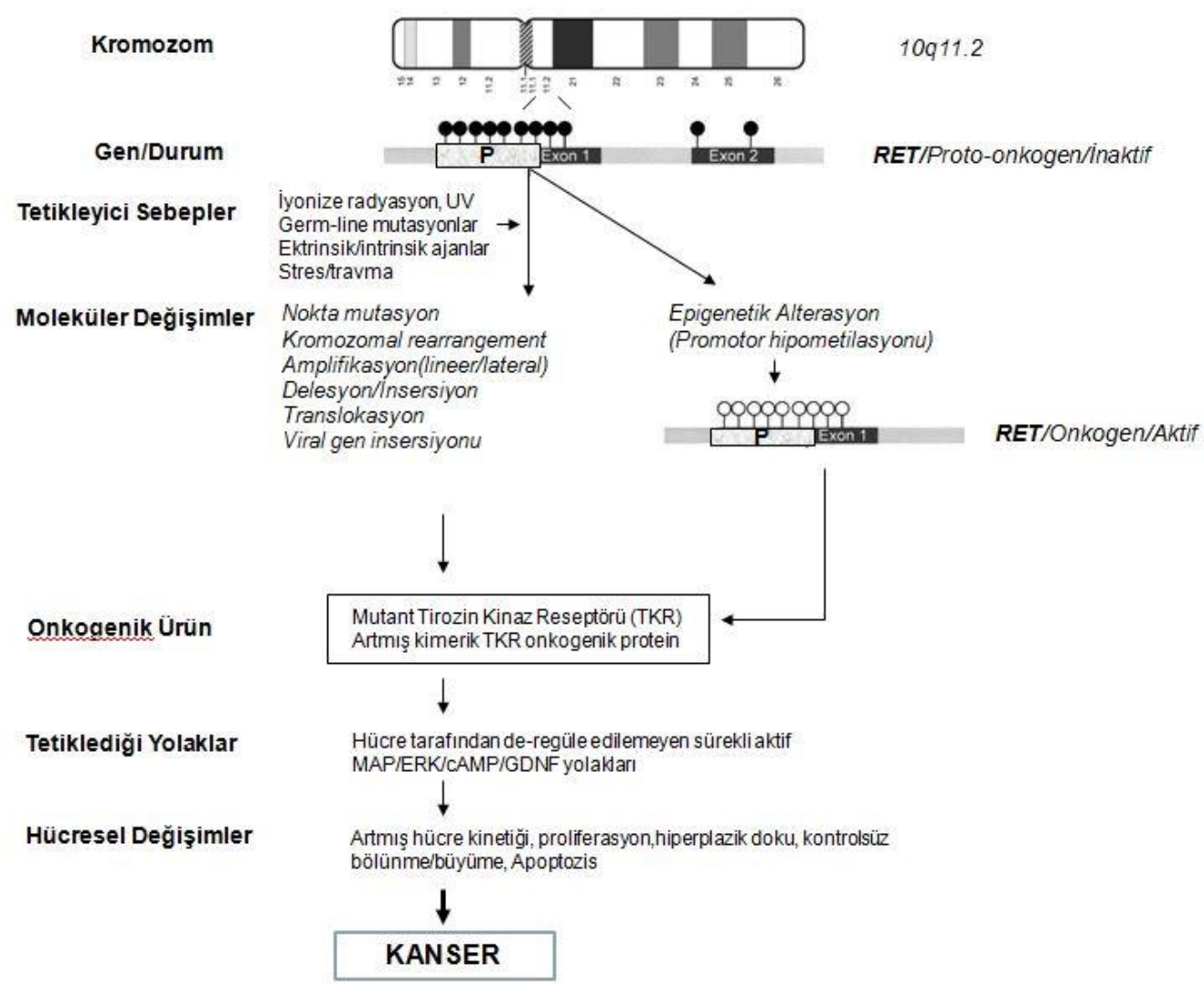

Şekil 1. Tiroid doku tümörlerinde yaygın olarak bildirilen $R E T$ proto-onkogenin kanser etkeni bir onkogene dönüşürken etkili tetikleyiciler, mutasyon tipleri, sentezlenen onkogenik protein ve kanserleşme sürecinde kullandığı etki yolakları.

Onkogen aracilı tiroid kanseri ilk kez 1987'de fusca ve ark. [20] tarafindan RET/PTC rearrangementı olarak bildirilmiştir. Daha sonra bu konuda bir çok çalışma yapılmış ve bir çok onkogen bildirilmiştir. Tiroid kanserlerinde onkogen mutasyon insidansının yaşa bağlı olarak arttığı iddia edilmektedir. Şimdiye kadar tiroid kanserinde etken olduğu bildirilen onkogenler ise şunlardır [21], (Tablo 1). 
Tablo 1. Yaygın tiroid doku kanserleri başlangıcında ve progresyonunda görev alan protoonkogenler, kromozomal lokalizasyonları, yaygın mutasyon tipleri (hotspots) ve bildirilmiş mutasyon yüzdeleri.

\begin{tabular}{|c|c|c|c|c|c|c|c|c|}
\hline Proto-onkogen & $\begin{array}{l}\text { Kromozomal } \\
\text { lokalizasyon }\end{array}$ & Mutasyon Tipi & Protein & Metabolik Yolak & $\begin{array}{l}\text { Preve } \\
\text { PTK }\end{array}$ & $\begin{array}{l}\text { ms (\%) } \\
\text { FTK }\end{array}$ & DTK & UDTK \\
\hline$\overline{B R A F}$ & & V600E*, V600D & & & & & & \\
\hline & $7 \mathrm{q} 34$ & $\mathrm{~V} 600 \mathrm{~K}, \mathrm{~V} 600 \mathrm{R}$ & Serin Treonin kinaz & RAS/RFF/MEK/ERKMAPK & $28-83$ & 10 & Nadir & Nadir \\
\hline$H-K-N-R A S$ & $12 \mathrm{p} 12.1$ & $\begin{array}{l}\text { Codon } 12^{8} \\
\text { Codon } 13 \\
\text { Codon } 61\end{array}$ & GTPaz & MAPK & 10 & 50 & 10 & 40 \\
\hline RET & $10 \mathrm{q} 11.21$ & Nokta mutasyon & Tirozin kinaz reseptör & $\begin{array}{l}\text { GDNF (Glial-cell line derived neurotrophic } \\
\text { factor) }\end{array}$ & $35-50$ & 10 & $10-20$ & Nadir \\
\hline RET/PTC & $10 \mathrm{q} 11.21$ & Rearrangement & Tirozin kinaz reseptör & $\begin{array}{l}\text { GDNF(Glial-cell line derived neurotrophic } \\
\text { factor) }\end{array}$ & $30-40$ & - & $10-20$ & Nadir \\
\hline NRTK-1 (TRK) & $1 \mathrm{q} 22$ & Nokta mutasyon Rearrangement & GTPaz & NGF(Nerve-growth faltör) & 10 & 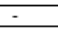 & Nadir & Nadir \\
\hline B-Catenin & $3 \mathrm{p} 22.1$ & Nokta mutasyon & E-cadherin & WNT & & - & 25 & 65 \\
\hline C-MET & $7 q 31.2$ & $\begin{array}{l}\text { Amplifikasyon ve veya intronik bölge } \\
\text { mutasyonu }\end{array}$ & Tirozin kinaz reseptör & Hepatosit büyüme faktörü & $70-80$ & 10 & $70-80$ & - \\
\hline $\begin{array}{l}\text { Nükleer onkogenler } \\
\text { c-myc } \\
c \text {-jun } \\
c \text {-fos }\end{array}$ & $\begin{array}{l}8 q 24.21 \\
1 p 32-p 31 \\
14 q 24.3 \\
\end{array}$ & Nokta mutasyon & HMGl nükleer protein & Nükleer transkripsiyon fahtörleri & Nadir & Nadir & - & Nadir \\
\hline
\end{tabular}

B.1.1. BRAF (v-raf murine sarcoma viral oncogene homolog B1) proto-onkogeni: $B R A F$ geni, hücre siklusunun kontrol yolakları olan RAS-RAF-MEK-ERK-MAPK yolaklarında önemli rolü olan bir gendir. Bu yolakları kullanarak hücre proliferasyonunda ve cyclin-D1 aktivasyonunda etkili olur [22]. Memeli hücrelerinde üç tane serin-treonin kinaz $R A F$ izoformları bulunmaktadır ( $A R A F, B R A F, C R A F)$. BRAF proto-onkogeni büyük oranda yapısal gen mutasyonu yoluyla onkogene dünüşürken, DNA hipometilasyonu yoluyla da onkogenik etki göstermektedirler (Şekil 2). BRAF mutasyon prevelans1 papiller tiroid kanserinde en s1k bildirilen mutasyon tipidir (\%28-83). Hatta son çalışmalar papiller mikrokarsinomunda da $B R A F$ aktivasyonunu işaret etmektedirler. Ayrıca papiller tip kanserlerin dediferansiasyonu sonucu gelişen anaplastik kanserlerde de $B R A F$ mutasyonundan bahsedilmektedir [23]. Papiller kanser araştırılırken IİAB da ya da cerrahi materyalde $B R A F$ bakılması iyi bir diagnostik markırdır ve spesifiteyi arttırmaktadır. Hatta bazı yayınlarda tall-cell varyant papiller kanserlerde $B R A F$ mutasyon prevelansını \%100 olarak bildirilmektedir. $B R A F$ mutasyon prevelansı en sik bildirilen mutasyon olmakla birlikte $B R A F$ ile hastalık agresifliği arasında ilişki saptanmamıştır. Radyasyon nedenli papiller kanserlerde ve folliküler kanserlerde ise $B R A F$ mutasyonu bildirilmemektedir [23-25]. Diğer taraftan literatürde $B R A F$ mutasyonu bulunan tiroid kanserlerinin prognozunun daha kötü olduğundan ve kemoterapi cevabını olumsuz etkilediğinden bahseden çok sayıda yayın bulunmaktadır. Yine bu vakalarda daha agresif cerrahiye gidilmesi ve eksternal radyoterapi verilmesi tavsiye edilmektedir. Ayrica BRAF mutasyonu ile iyot tutma oranları arasinda anlamlı korelasyonlar bulunmuştur. $B R A F$ mutasyonlu olgularda iyot tutulmasında etkili olan NIS enzim ekspresyonunun belirgin düşük olduğu saptanmıştır [26]. Son yayınlarda $B R A F$ 'ın gerek teşhişte ve prognoz belirlemede gerekse tedavide önemli bir moleküler markır olduğu kesinlik kazanmıştır.

B.1.2. RAS (rat sarcoma 2 viral oncogene homolog) proto-onkogeni: $R A S$, tirozin-kinaz sinyal yolunda görev alan bir sinyal proteinidir. $R A S$ proto-onkogeninden, $H R A S, K R A S A$, $K R A S B$ ve $N R A S$ olmak üzere dört $R A S$ onkogeni kodlanmaktadır. $R A S$ proto-onkogen mutasyonları hücre malignant transformasyonunda ve insanda birden fazla kanser tipinin progresyonunda rol oynar [27]. RAS proto-onkogeni onkogene dönüştüğünde, reseptör alt biriminden yoksun transmembran bir G proteini sentezlenir. Sentezlenen bu protein sürekli olarak GTPaz aktivitesi göstermektedir. Normal GTPaz dan farklı olarak bu mutant GTPaz hücre tarafindan kontrol edilememekte ve hücrenin mitotik aktivitesi artmaktadır. $R A S$ onkogeni aynı şekilde MAPK yolağını kullanarak da hücre mitotik aktivitesini arttırmaktadır. Tiroid folliküler ve anaplastik kanserlerinin \%40-50'sinde KRAS mutasyonu bildirilmekte iken papiller kanserlerinde KRAS mutasyonu nadiren bildirilmektedir [28]. Son yapılan araştırmalar tiroglobulinin ekspresyonunun az ya da hiç olmadığı tümörlerde NRAS kodon 61 mutasyonun daha sik olduğu (hotspot) bildirmektedirler. Mutant KRAS varlığı anti-EGFR tedavisinde yanıtı büyük oranda etkisiz kılmaktadır [29]. Bu nedenle Amerika Klinik Onkoloji Birliği tüm metastatik 
tümörlerin anti-EGFR tedavisine başlamadan önce $K R A S$ exon 2 kodon 1213 ve 61 mutasyonları açısından genotiplendirilmesini önermektedir [30].

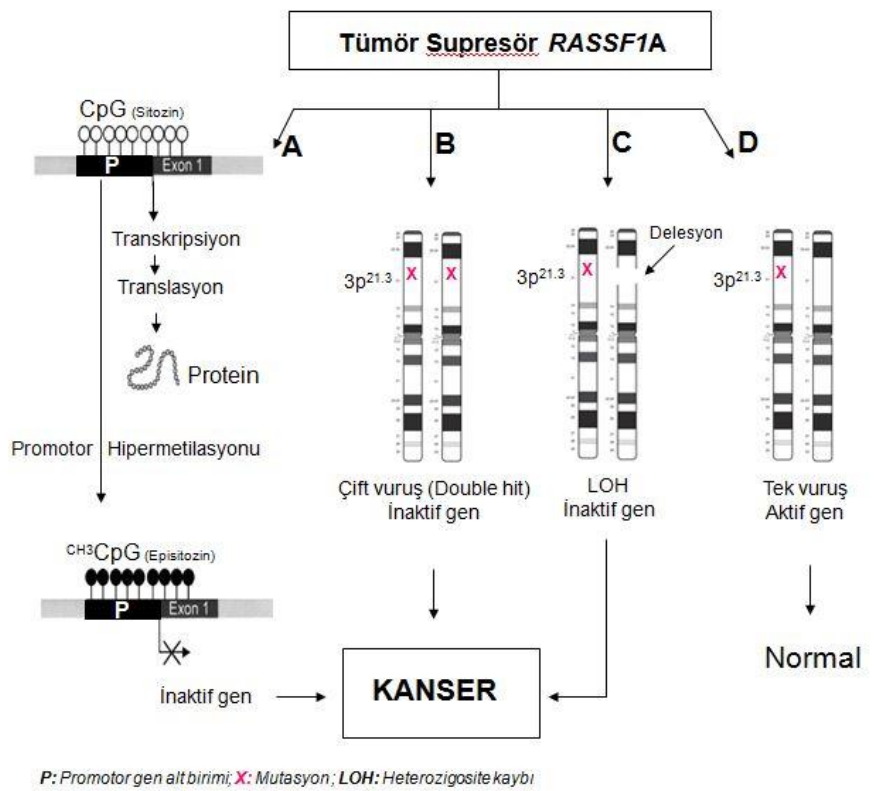

Şekil 2. Organizmanın bütün hücrelerinde aktif bir fonksiyonel gen olan (Housekeeping) tumör supresör RASSF1A genin insanda kromozomal lokalizasyonu ve kanserde etkeni olmasına neden olan mekanizmalar.

A. Epigenetik alterasyon; başlangıçta protein sentezleyen aktif gen, promotor bölge DNA hipermetilasyonu ile inaktif hale gelir ve tumör supresif etkisi ortadan kalkar.

B. Çift vuruş (Double Hit); başlangıçta protein sentezleyen aktif gen, atasal her iki allelde meydana gelen yapısal nokta mutasyon ile inaktif hale gelir ve tumör supresif etkisi ortadan kalkar.

C. Heterozigosite kaybı(LOH); başlangıçta protein sentezleyen aktif gen, atasal allelin birinde yapısal nokta mutasyon ve diğerinde ise kromozomal bölge delesyonu sonrası gen tamamen inaktif hale gelir, protein sentezine katılmaz ve tumör supresif etkisi ortadan kalkar.

D. Normal Hücre; Kanserde onkogenlerin aksine, otozomal resesif kalıtılan tumör supresör genlerde her iki allelden birisinde meydana gelen tek vuruş mutasyona sonrası, alternatif allel normal fonksiyon yaptığı için kanser tetiklenmez veya tetiklenmiş kanserin ilerlemesine katkı vermez.

B.1.3. RET (Rearranged during transfection) proto-onkogeni: RET proto-onkogeni kromozom 10q11.21 kolunda lokalizedir ve TGF- $\beta$ - related nörotrofik faktör bağlayan bir tirozin kinaz reseptör proteinini kodlar. RET proto-onkogeni normal olarak nöral krest kökenli hücre tiplerinde eksprese olmaktadır. Bu nedenle sadece nöroektodermal kökenli parafolliküler ve $\mathrm{C}$ hücrelerinden köken alan medüller tiroid kanserlerinde saptanmaktadır [27, 31]. Çeşitli germ-line ve somatik RET mutasyonları ya da promotor hipometilasyonu sonucu reseptör TK aktivitesi sürekli olarak uyarılarak multiple endokrin neoplazi tip 2 sendromlarına (MEN2A, MEN2B ve familial medüller tiroid kanseri) yol açmaktadır (Şekil 3) [32].

B.1.4. RET/PTC proto-onkogeni: İyonize radyasyonun tiroid kanseri etyopatolojisinde önemli bir yeri vardır. İyonize radyasyon ekstrinsik kaynaklı mutajenlerin başında gelir [33]. Ancak iyonize radyasyon maruziyeti olan her olguda hücre transformasyonu olmamakta yani kanser gelişmemektedir. $\mathrm{Bu}$ durumda en önemli faktör, iyonize radyasyona maruz kalan solid dokudaki hücrelerin mitotik indeks s1klığ 1 ve hangi hücre evresinde bulunduğudur. Transformasyon riski en yüksek olan hücrenin, bölünmekte olan ve $S$ evresinde olan hücre olduğu bilinmektedir. Yine iyonize radyasyonun neden olduğu mutasyonların çoğunun, insan genomunun \%98'ini meydana getiren ve mutasyondan koruyucu mekanizma olan non-genomik (protein karşılığ1 olmayan) DNA bölgesinde meydana gelmesi kanserden koruyucu bir mekanizmadır. Buna rağmen bazı olgularda 
iyonize radyasyon eukaryotik genomda düşük olasılıkla da olsa fonksiyonel genlerde (onkogen-tümör supresyon gen ve diğer) başta nokta mutasyon, delesyon, translokasyon ve kromozomlar arası rearragementlar'a neden olmaktadır. Tiroid dokularında bir protoonkogen olan RET iyonize radyasyon maruziyetinde en yaygin olarak rearragement olan bir gendir. RET onkogeni şimdiye kadar bildirilmiş 15 tip fonksiyonel donör genle, bölge değişimi yaparak yeniden düzenlenmeye (rearrengement) uğramaktadır (Tablo 2). Bu rearrengementlar ilk kez papiller tiroid kanserinde bildirilmiş olduğundan RET/PTC olarak adlandırılmışıı [34]. Tiroid spesifik RET/PTC geni ilk kez 1987 yılında bildirilmiştir [20]. Bugüne kadar 15 adet RET/PTC rearrangement'1 tanımlanmış olmakla birlikte tiroid kanseri için ilk üç tanesi önemli olmuştur. $\mathrm{Bu}$ rearrangement'ın gelişmesinde iyonize radyasyonun rolü çok fazladır. Bu durum birçok invivo çalışmayla kanıtlanmıştır. Radyasyon uyarımlı tiroid karsinomların büyük oranınında RET/PTC rearrangement'ının yüksek düzeyde olduğu bildirilmiştir [27, 34]. Rearrangement olan $R E T$ geni kontrol edilemeyen aşırı tirozin kinaz reseptör proteini sentezleterek hücreleri transformasyona götürebilmektedir. Agresif ve non-agresif kanserlerdeki RET rearrangement ekspresyon düzeyleri tiroid papiller kanser tanı ve takibinde önemlidir. RET/PTC-1 sporadik papiller kanserlerin \%35-50'sinde bildirilmiştir. Ancak literatürde Çernobil nükleer kazasından sonra radyasyon maruziyetine bağlı gelişen tiroid kanserlerinde \%80'e varan RET/PTC mutasyon oranları bulunmaktadır. Çok sayıda çalışma Çernobil sonrası Belaruslu yetişkin ve çocuklarda oluşan tiroid kanserlerinin \% $\% 0$ ninde RET/PTC aktivasyonu bildirilmektedir. RET/PTC onkogen aktivasyonu papiller tiroid kanserine sınırlı gibi görünse de başka tip tiroid kanserlerinde de rastlanılmıstır; örneğin herediter medüller tiroid kanseri olgularında RET proto-onkogeninde germline mutasyon bulunmaktadır. Transgenik farelerde yapılan bir çalışmada RET/PTC1'in nonmetastatik tiroid tümörlerine neden olduğu, RET/PTC3'ün ise metastaz gelişimine neden olduğu gösterilmiştir. RET/PTC aktivasyonu okült PTK' da \%77, klinik olarak belirgin kanserlerde $\% 47$ oranında belirlenmistir. Bu nedenle RET/PTCl'in papiller tiroid kanserinin baslangıcında, RET/PTC3'ün ise kanserin yayılımında (agresivite) rolleri olduğu düşünülmektedir $[33,35]$.

B.1.5. NTRK-1 (nötrofilik tirozin kinaz tip 1): NTRK-1 ya da eski adiyla TRK, sinir büyüme faktörlerinin bağlandığı transmembran tirozin kinaz reseptörünü sentezler. Bir nokta mutasyon ya da kromozom 1 ve 3 üzerine lokalize diğer bazı fonksiyonel genlerle (NTRK1/T1, NTRK1/T2, NTRK1/TFG) rearrangement sonras1 mutant protein ve/veya kimerik protein şeklinde sentezlenir. Böylece ligand bağımsız olarak sürekli aktivite göstererek hücre transformasyonunu başlatır. Çernobil sonrası papiller karsinomalarda NTRK1 aktivasyonu ender bildirilirken, son zamanlarda medüller karsinomların patogenezinde önemli olduğu varsayılmaktadır $[33,36]$.

B.1.6. $\beta$-catenin: $\beta$-catenin CTNNBI tarafından kodlanan hücre adezyonunda ve transkripsiyonunda rol oynayan multifonksiyonel bir proteindir. Wnt yolağını kullanarak hücrelerarası adezyonu sağlar. Sitoplazmada E-cadherin ile $\beta$-catenin kompleks oluşturarak apopitoz inhibisyonu ve hücre proliferasyonunu stimüle eden genlerin transaktivasyonunda rol alır. $\beta$-catenin bu rolünden dolayı onkogen olarak tanımlanmaktadır. Zayıf ve kötü diferensiye tiroid kanserlerinde E-cadherin ekspresyonu düşük seviyede tespit edilmiş ve $\beta$-catenin mutasyonu (\%25-65) saptanmıştır. Bu nedenle düşük E-cadherin ekspresyonu ve $\beta$-catenin mutasyon varlığının tiroid kanser dediferansiasyonuna ve progresyonuna eşlik eden faktörler olduğu düşünülmektedir $[14$, $27,34,37]$. 


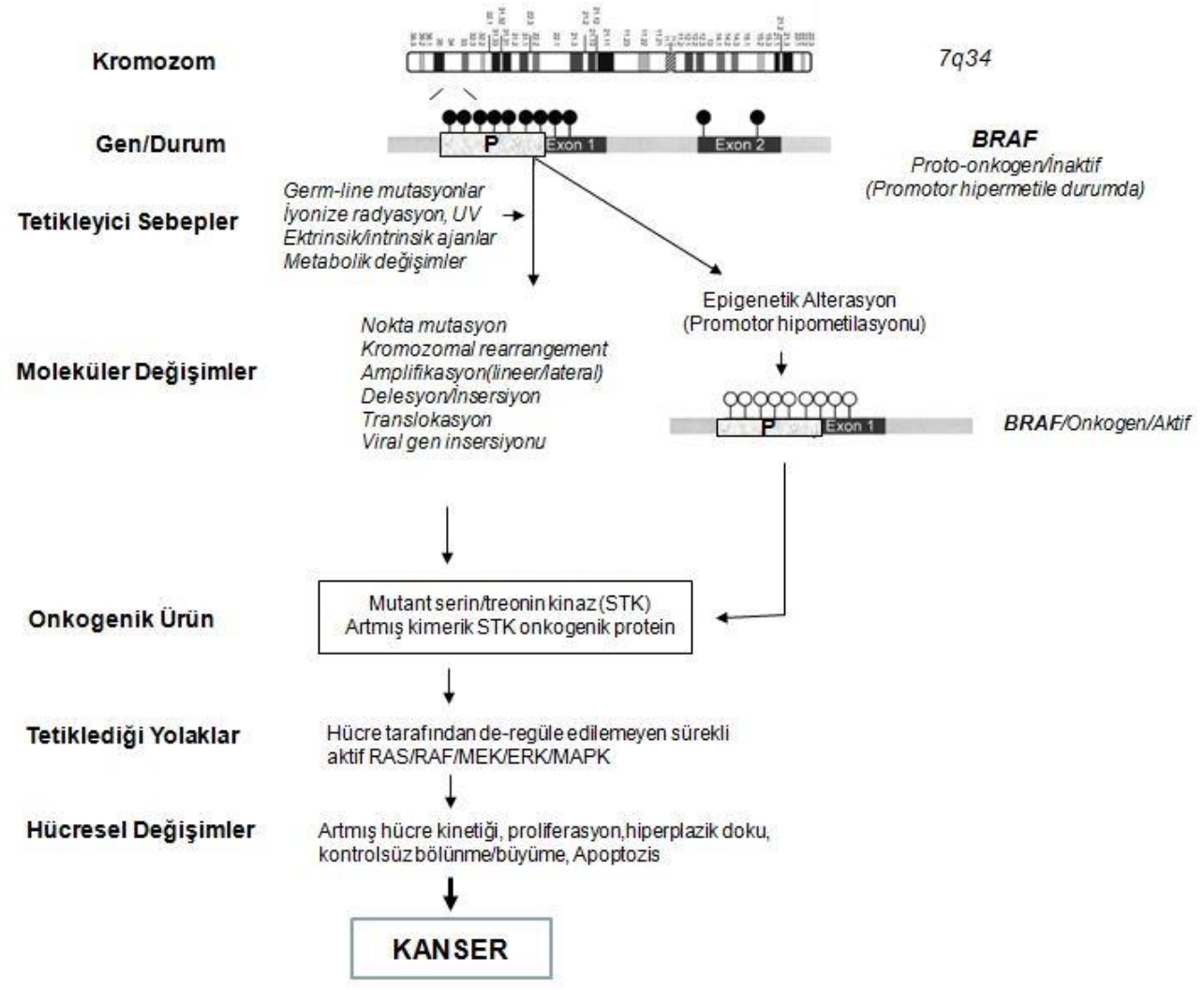

Şekil. 3. Kromozom $7 q 34$ de lokalize proto-onkogen $B R A F$ 'ın hücre transformasyonuna neden olacak onkogene dönüşmesinde etkili tetikleyiciler, mutasyon tipleri, onkogenik protein, hücrezel değişimler ve kanserleşme sürecinde kullandığı etki yolakları.

Tablo 2. Tiroid doku tümörlerinde bildirilmiş $R E T$ proto-onkogenin en yaygın transloke olduğu (Rearrangement) fonksiyonel donör genler ve hücrede artmış kimerik onkogenik protein sentezinden sorumlu rekombine gen profilleri.

\begin{tabular}{llll}
\hline Proto-Onkogen & Fonksiyonel donör gen & Kimerik onkogen & Radyasyonla ilgisi \\
\hline RET 10q11.2 & CCD6(H4) & RET/PTC1 & Nadir \\
& PRKARlA & RET/PTC2 & Nadir \\
& NCO4(Ele1) & RET/PTC3 & + \\
NCO4(Ele1) & RET/PTC4 & + \\
GOLGA5 & RET/PTC5 & + \\
& TRIM24 & RET/PTC6 & + \\
TRIM33 & RET/PTC7 & + \\
KTN1 & RET/PTC8 & + \\
RFG9 & RET/PTC9 & + \\
ELKS & RET/ELKS & + \\
PCM1 & RET/PCM1 & + \\
TRIM27 & RET/TRIM27 & + \\
HOOK3 & RET/HOOK3 & - \\
PTCH1 & RET/PTCH1 & $?$ \\
PTCH2 & RET/PTCH2 & $?$ \\
\hline
\end{tabular}

B.1.7. C-met proto-onkogeni: Tirozin kinazlar malignant hücre transformasyon yolağında çok önemli genlerdir. İnsan tiroid dokularında 21 farklı tirozin kinaz tanımlanmıştır. Bu tirozin kinazların birçoğu hücre proliferasyonu ve diferansiyonunun regülasyonunda rol alırlar. Dİferansiye tiroid kanserlerinde tirozin kinaz over ekspresyonu bildirilmiştir. En önemli tirozin kinazlardan bir tanesi c-met tarafından sentezlenen ve iki subunitten ibaret $190 \mathrm{Kda}$ büyüklüğünde bir transmembran proteini 
olan hepatosit büyüme faktörüdür. Hepatosit büyüme faktörü, tiroid folliküler hücrelerini de içeren tüm epitelial hücrelerde mitojenik etkili bir proteindir [27]. Özellikle papiller tiroid kanserlerinin \%70-80'inde bu şekilde C-met over-eskpresyonu bildirilmiştir. Aynı şekilde $C$-met gen over-ekspresyonu agresif varyant tiroid papiller kanserlerinde lenf nodu metastazlarında yaygın olarak bildirilmektedir [27, 38]. Bu sebeple $C$-met overekspresyonun ileri tümör evrelendirilmesinde indikatör bir markır olabileceği bildirilmektedir.

B.1.8. Nükleer onkogenler: Tiroid onkogenezinde rol oynayan en önemli transkripsiyon faktörleri aynı isimli proto-onkogenlerce eksprese edilen myc, jun, fos proteinleridir. $C$ $m y c, c$-jun, $c$-fos gibi proto-onkogenler mutasyona uğradıklarında (aktifleştiğinde) hücre büyüme ve farklılaşmasının kontrolünde görev alan nükleer transkripsiyon faktörleri üretirler. Tiroid kanserlerinde aşırı ekspresyonu bildirilmektedir. Bu proteinler normal tiroid dokusunda, guatr dokusunda ve folliküler adenomlarda bulunmadığından malignant tiroid tümörlerinde önemli bir moleküler markır olarak kabul edilmektedirler [27].

B.2. Tümör supresör gen aracılı tiroid kanserleri: Yüksek canlılarda tanımlanmış 50 civarında tümör supresör gen bulunmaktadır. Temel fonksiyonları hücre çoğalmasını kontrol etmektir. Tümör supresör genler, bozulmuş hücre döngüsünün devamını engelleyerek, gerektiğinde hücreleri apoptozise yönlendirirler. Hücre içerisinde DNA replikasyonu ve tamirinin hatasız şekilde gerçekleşmesini sağlayarak hücre çoğalmasını kontrol altında tutarlar. Organizmanın bütün hücrelerinde ve hücrelerin bütün siklusu boyunca aktif olarak (house-keeping gen) bulunurlar. Tümör supresör genler resesif kalıt1lırlar ve inaktif oldukları durumda onkogenez sürecine katkı verirler. Resesif kalıtım gösterdiklerinden inaktif olabilmeleri için her iki allelin birlikte fonksiyon kaybına uğraması gerekmektedir. İnaktivasyonları, nokta mutasyon, delesyon mutasyon, promotor metilasyon, miRNA aracılı ve epigenetik değişiklikler gibi değişik mekanizmalarla gerçekleşebilir. Her iki allellin fonksiyon kaybına uğraması durumu çift vuruş (double hit) olarak bilinir. Diğer taraftan allerlerden birinde mutasyon diğerinde delesyon olmas1 durumunda da [loss of heterogenite $(\mathrm{LOH})]$ tümör supresyon genler inaktif hal alırlar [11], (Şekil 4). Tiroid kanserinde etkili olduğu bildirilen tümör supresör genler şunlardır; pTEN, RASSF1A, PAX8/PPAR , p53, MGMT, DAPK1, p16, THR beta, Rap1GAP (Tablo $3)$. Bu genlerden önemli olan bazılarının tiroid kanserindeki rolleri şu şekildedir.

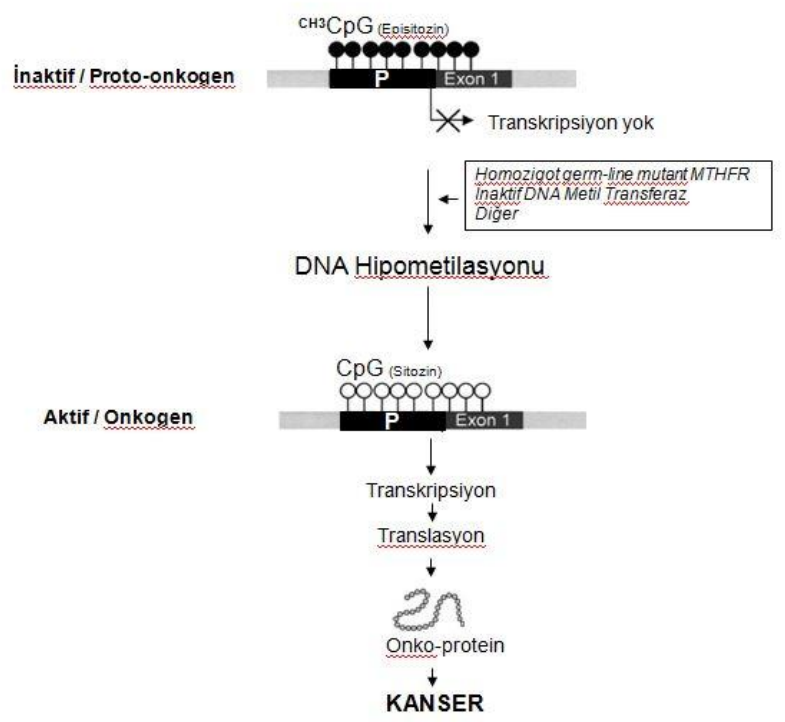

Şekil 4. Epigenetik kalıtımın proto-onkogen reaktivasyonu yolu ile tiroid kanserindeki önemli rolü. Organizmanın bütün hücrelerinde promotor bölge hipermetilasyonu ile onkogenler proto-onkogenler olarak inaktive edilir. Tumör supresör genlerin aksine protoonkogeneler, DNA hipometilasyonu sonrası çok aşmalı kansere tetikleyici ve/veya ilerleticiler olarak görev alırlar. 
Tablo 3. Bir yapısal mutasyon ve/veya promotor hipermetilasyonuna bağlı inaktivasyonla çeşitli tiroid kanserlerinde tümör supresör aracılı onkogenezise neden olan genler, etki yolakları, homozigot inaktivasyon oranları (Double hit/çift vuruş) ve insanda lokalize oldukları kromozom bölgeleri.

\begin{tabular}{|c|c|c|c|c|}
\hline $\begin{array}{l}\text { Tumör } \\
\text { Supresör Gen } \\
\end{array}$ & $\begin{array}{l}\text { Kromozomal } \\
\text { Lokalizasyonu }\end{array}$ & Fonksiyon & $\begin{array}{l}\text { Tiroid } \\
\text { KanserTipi }\end{array}$ & $\begin{array}{l}\text { İnaktivasyon oranı } \\
(\%),(\text { Homozigot })\end{array}$ \\
\hline \multirow{3}{*}{ pTEN } & \multirow{3}{*}{$10 q 22-23$} & \multirow{3}{*}{ PI3K/Akt yolağında görevli } & PTK & 2 \\
\hline & & & FTK & 15 \\
\hline & & & ATK & 23 \\
\hline \multirow{4}{*}{$\begin{array}{l}\text { RASSF1A } \\
\text { /MST1 }\end{array}$} & \multirow{4}{*}{$3 \mathrm{p} 21.31$} & \multirow{4}{*}{$\begin{array}{l}\text { Hücre döngü progresyon } \\
\text { inhibisyonu, apopitozis }\end{array}$} & PTK & 60* \\
\hline & & & FTK & $70 *$ \\
\hline & & & MTK & $80 *$ \\
\hline & & & ATK & 80* \\
\hline$P A X 8 / P P A R \gamma$ & $2 q 13 / 3 p 25$ & Tam olarak bilinmiyor & FTK & 35 \\
\hline \multirow{3}{*}{$p 53$} & \multirow{3}{*}{$17 \mathrm{p}$} & Apopitoz, & PTK & $0-9$ \\
\hline & & \multirow{2}{*}{$\begin{array}{l}\text { Tumor progresyonu ve } \\
\text { invazyonu }\end{array}$} & FTK & 67-88* \\
\hline & & & ATK & \\
\hline \multirow{3}{*}{$M G M T$} & \multirow{3}{*}{$10 q 26.3$} & \multirow{3}{*}{$\begin{array}{l}\text { DNA tamiri }(\mathrm{A} / \mathrm{G} \\
\text { transisyonları) }\end{array}$} & PTK & \\
\hline & & & MTK & $5-25$ \\
\hline & & & ATK & \\
\hline \multirow{2}{*}{ p16/CDKN2A } & \multirow{2}{*}{$9 \mathrm{p} 21.3$} & \multirow{2}{*}{ CDK4 inhibitörü } & PTK & Deŏisen oranlarda \\
\hline & & & FTK & Degişen oranlarda \\
\hline \multirow[t]{2}{*}{ THR beta } & \multirow[t]{2}{*}{$14 q$} & \multirow[t]{2}{*}{ Tiroid hormon aktivasyonu } & PTK & 30 \\
\hline & & & FTK & 33 \\
\hline DAPK1 & $9 \mathrm{q} 34.1$ & Apopitoz aktivasyonu & $\begin{array}{l}\text { Tiroid } \\
\text { lenfoma } \\
\text { ATK }\end{array}$ & 20 \\
\hline Rap1GAP & $9 \mathrm{p} 21.96$ & $\begin{array}{l}\text { GTPaz aktivasyonu Tumor } \\
\text { progresyonu ve invazyonu } \\
\text { üzerinde etkili }\end{array}$ & ATK & 40 \\
\hline
\end{tabular}

B.2.1. pTEN (Phosphatase and Tensin homolog deleted on chromosome Ten): pTEN kromozom 10q 22-23 de lokalize bir tümör supresör gendir. Tümörogeneziste önemli bir yolak olan fosfatidil inositol-3'-kinaz (PI3K)/Akt yolağında görev alır. (PI3K)/Akt yolağ 1 hücresel metabolizmanın kontrolünde özellikle glukoz transportu ve kullanımı, hücre büyümesinin regülasyonu, protein biyosentezi ve apopitozun önlemesinden sorumludur. pTEN bu yolağın negatif düzenleyicisidir. Çeşitli mutasyonlar ve promotor hipermetilasyonu ile $p T E N$ 'in inaktive olması birçok tipte kanser gelişimine katkıda bulunmaktadır. pTEN mutasyonları papiller tiroid kanserinde $\% 2$, follikülerde $\% 15$, anaplastik tiroid kanserinde ise $\% 23$ oranlarında bildirilmektedir [39].

B.2.2. RASSF1A (Ras association (RalGDS/AF-6) domain family member): RASSF1A, hücre döngü progresyonunun ve siklinD1 akümülasyonunun inhibisyonunda rol alır. Ayrıca RASSF1A, apoptotik protein kinaz MST1'e bağlanarak apopitoz yolağını kontrol eder. RASSF1A inaktivasyonu, nokta mutasyon, delesyon mutasyon, promotor metilasyon, ve epigenetik değişiklikler gibi değişik mekanizmalarla gerçekleşebilir. Resesif kalıtım gösterdiklerinden her iki RASSF1A gen allellinin fonksiyon kaybına uğraması gerekmektedir (çift vuruş=double hit). Diğer taraftan allerlerden birinde mutasyon diğerinde delesyon olması durumunda da [loss of heterogenite (LOH)] RASSF 1A geni inaktif hal alır [40]. RASSF1A hipermetilasyonu insan kanserlerinin birçok tipinde en sık rastlanılan tumör supresör gen değişikliğidir [41] (Şekil 4). Tiroid kanserlerinin anaplastik ve medüller tiplerinde $\% 80$, papiller ve folliküler tiplerinde ise \%60-70 oranında RASSF1A homozigot promotor hipermetilasyonu bildirilmektedir [42]. 
B.2.3. PAX8/PPAR rearrangement: $P A X 8$ geni bir transkripsiyon faktörü sentezleyerek embriyonal dönemde tiroid folliküler hücrelerin ilkin farklılaşmasında görev alır [29, 43]. $\mathrm{Bu}$ genler yetişkinlerde promotor gen hipermetilasyonuyla inaktive edilirler. Yetişkinlerde tiroid folliküler hücreleride dahil hiçbir somatik hücrede eksprese edilmezler. Ancak $P A X 8$ geni, peroksizom proliferatör-aktivatör reseptör $(P P A R \gamma)$ geniyle siklikla rearrangement olarak yeniden ekspresyon kazanabilmektedirler. $P P A R \gamma$ tiroid hormonu, retinoik asit, androgen ve östrogen reseptörlerini de içeren nükleer hormon reseptör süper ailesinin bir üyesidir. $P A X 8 / P P A R \gamma$ rearrangement'ının onkogenezdeki etki mekanizması ortaya konamamakla birlikte $P A X 8 / P P A R \gamma$ rearrangement'1 esnasında bir tümör supresör gen olan $P P A R \gamma$ 'in inaktive olmasindan kaynaklanabileceği varsayılmaktadır. $P A X 8 / P P A R \gamma$ rearrangment'larının $R A S$ mutasyonlarında olduğu gibi tiroid folliküler kanser gelişimiyle ilişkili olduğu (\%35) düşünülmektedir [30, 44].

B.2.4. p53: Bir tümör supresör gen olan $p 53$, transkripsiyonu regüle eden $p 53$ proteinini kodlar. p53 proteini hücre homeostazisinde önemli rol oynar. Hasarlı DNA'nın onarılmasında ve apoptoziste düzenleyici etkileri vardır. P53 geninde meydana nokta mutasyonlar sonucunda bu protein inaktive olur. Defektif p53 yolağ karsinogenesizte, kanser progresyonunda ve kanser tedavisi direncinde önemli rol oynamaktadır. İyi diferensiye tiroid kanserlerinde p53 mutasyonuna pek rastlanmazken (\%0-9), anaplastik ve kötü diferansiye tiplerinde sıkça (\%67-88) rastlanmaktadır [23, 37, 45].

B.2.5. MGMT (O6 Metilguanin-DNA metiltransferaz): MGMT normal hücrelerde bulunan hücresel DNA tamir proteinidir ve guanin'in O6 pozisyonundaki alkilasyonunu (metilasyonu) hızla geri çevirerek alkilleyici ajanların sitotoksik etkisini azaltarak karsinogenezisi durdurduğu için tümör supresörü olarak rol alır. Alkilleyici ajanlara maruz kalındığında DNA üzerinde meydana gelen hasarı onarmak için MGMT ekspresyonu artmaktadır. Birçok kanser tipinde olduğu gibi tiroid kanserlerinde de artmış MGMT ekspresyonunu bildiren yayınlar bulunmaktadır [45, 46].

B.3. Fonksiyonel gen aracılı tiroid kanserleri: İnsanda tanımlanmış 20-25 bin adet fonksiyonel gen bulunmaktadir. $\mathrm{Bu}$ genlerden sentezlenen fonksiyonel proteinlerin hücrelerdeki rolleri çok çeşitlidir. Histon protein genleri ve MTHFR gibi çoğu genler organizmanın bütün hücrelerinde ve hücrelerin bütün hayat siklusları boyunca aktif halde bulunurlar. Diğer yandan sodyum iyodür symporter (NIS) proteini ve hormonların sentezlendiği bazı genler ise sadece belli doku ve hücre gruplarında aktiftirler. Bundan dolayı bu genlere doku spesifik genler denir. Bu gen grubu organogenez ve doku farklılaşması sürecinde promotor hipermetilasyonu ile primer olarak inaktive edilirler. Tümör doku kimliklendirme çalışmaları, kanser oluşumunda sadece onkogen ve tümör supresör genler fonksiyon yapmadığını, aynı zamanda bazı fonksiyonel genlerin mRNA ekspresyonlarının da düşük olduğunu göstermiş̧tir. Tiroid kanser gelişiminde etkili olduğu ortaya konabilmiş fonksiyonel genler Tablo 4'te verilmiştir. Bu genlerden önemli olan bazıları şunlardır:

B.3.1. Tiroid stimülan hormon (TSH) ve reseptörü (TSH-R): TSH tiroid dokusunun büyümesi ve gelişmesi için önemli bir hormondur. TSH membranda lokalize TSH reseptörüne bağlandıktan sonra tiroid hücre epitel proliferasyonu stimüle eder ve hormon sentezinde ve doku farklılaşmasında önemli markırlar olan tiroglobulin, tiroperoksidaz ve NIS ekspresyonlarını düzenler. Tiroid hormon reseptörleri olan THR A ve B tiroid doku fonksiyonunda kilit düzenleyicidirler. Bu reseptörlerde meydana mutasyonlar veya epigenetik alterasyonlar tiroid kanserini de içeren birçok tiroid hastalıklarına neden olmaktadırlar. Bu reseptör mutasyonları en sık toksik nodüler guatr ve adenoma neden olmaktadırlar. Son literatür verilerine göre özellikle diferensiye tiroid kanserinde bu reseptörlerde yaygın genetik değişimler olduğunu bildirmektedirler. TSHR genindeki genetik değişimler iki yolla tiroid kanserlerine (tiroid hücre transformasyonuna) katk1 vermektedir; 
1. Fonksiyonel gen alt biriminde meydana gelen yapısal mutasyonlar.

2. Promotor bölge hipermetilasyonu; Fonksiyonel gen bölgesinde meydana gelen yapısal mutasyonlar hormon-reseptör özgüllüğünü kaybettirdiği gibi kontrol edilemez düzeyde arttırabilirler. Bu durumda çoğunlukla dokuda hiperaktif nodül oluşumuna neden olmakta ve bu durum adenom ve/veya toksik nodül ile sonuçlanmaktadır.

TSH yapısal mutasyonlarının neoplastik transfomasyondaki rolü çok açık olmamakla birlikte cAMP kaskatını sürekli aktive ederek tiroid malignensi gelişimine neden olduğu varsayılmaktadır. Mutant dimerik $G$ protein sentezine neden olan yapisal mutasyon sonrası, devamlı hücre içi cAMP kaskatını hücre kontrolü dışında aktive ederek ERK/MEK tirozin kinaz aktivitesi ile hiperproliferatif tiroid hücre transformasyonuna neden olmaktadır. Tiroid kanserlerinin FTK ve MTK tiplerinde \%2-20'sinde yapısal TSH reseptör mutasyonu bildirilmiştir. TSH promotor hipermetilasyon ise, yapısal gen mutasyonlarından daha sik rastlanılan bir durumdur. TSH promotor hipermetilasyonu veya yapısal gen mutasyonları bu gen bölgesinden az ya da hiç mRNA sentezine neden olmaktadır. TSH reseptörüne ait mRNA'nın azlığı yada yokluğu tümör dokuları dokularının diferensiyasyonu ile ilgili bir durumdur, iyi diferansiye dokularda az iken, kötü diferensiye tiplerde TSHR mRNA hiç sentezlenmemektedir. TSH reseptörü tiroid dokusunda NIS ekspresyonunu düzenlediği için bu reseptör deki düşüş tiroid kanserlerinin iyot tutma yeteneğini azaltır. Periferik dolaşımda TSH reseptör mRNA ölçümü önemli bir markır olarak kabul edilir. Nitekim bazı araştırıcılar bu kanser olgularında adjuan tedavi olarak demetiatör ajanların kullanıdığ 1 durumlarda tedavide önemli başarıların elde edilebildiğini bildirmektedirler [47, 48].

Tablo 4. Çoğunlukla germ-line mutant durumunda insanda özellikle ailesel tiroid kanserlerinde fonksiyonel gen aracılı primer ve/veya sekonder onkogeneziste etkili genler, ekspresyon durumları, sentezledikleri fonksiyonel protein ve etkili oldukları yaygın tiroid kanser tipi.

\begin{tabular}{|c|c|c|c|c|}
\hline Fonksiyonel gen & Ekspresyon durumu & Protein & Tiroid kanser tipi & Fonksiyon \\
\hline TSH ve TSH-R & Ekspresyon artı̧̧ı & TSH, THR A ve B & FTK, MTK & $\begin{array}{l}\text { Hücre epitel proliferasyonu ve } \\
\text { tiroid hormon sentezi }\end{array}$ \\
\hline Na/I symporter & Ekspresyon azalmas1 & Sodium iodide symporter & PTK, FTK, MTK,ATK & Hücre içine iyot alınması \\
\hline TTF1 & Ekspresyon artı̧̧1 & Tiroglobulin ve Tiroperoksidaz & PTK, FTK, MTK & $\begin{array}{l}\text { Tiroid dokusunun erken } \\
\text { diferansiasyonu ve morfogenezi }\end{array}$ \\
\hline MTHFR & Ekspresyon azalmas1 & Hücre içi metil sentezi & Genel onkogenezis & $\begin{array}{l}\text { Yetersiz }(\% 40-60) \text { metil } \\
\text { kaynağına bağli proto-onkogen } \\
\text { aktivasyonu }\end{array}$ \\
\hline MDR1 & Ekspresyon azalmas1 & Glikoprotein-P & PTK, FTK & Transmembran eflüx pompas 1 \\
\hline$\overline{P A X 8}$ & Ekspresyon artı̧̧ı & Transkripsiyon faktörü & PTK, FTK & $\begin{array}{l}\text { Embriyonel dönemde tiroid } \\
\text { gelişimi }\end{array}$ \\
\hline FOXE1 & Ekspresyon artış1 & Transkripsiyon faktörü & PTK & $\begin{array}{l}\text { Embriyonel dönemde tiroid hücre } \\
\text { farklilaşması ve migrasyonu }\end{array}$ \\
\hline CYP 450 & Ekspresyon azalmas1 & CYP450 enzimleri & Genel onkogenezis & $\begin{array}{l}\text { Ilaç ve ksenobiyotik } \\
\text { metabolizasyonu ve atilim1 }\end{array}$ \\
\hline MMP 3 ve 9 & Ekspresyon artıģ1 & Matriks metaloproteinaz & PTK agresif tümör, metastaz & İleri anjiogenezis \\
\hline$P c G$ & Ekspresyon artı̧̧1 & Policomb grup proteinler & PTK agresif tümör, metastaz & Düzensiz gen regülasyonu \\
\hline $\operatorname{COX} 2$ & Ekspresyon artı̧̧1 & Sitokin etkili protein & PTK, ATK & $\begin{array}{l}\text { Epitelial hücre bölünmesi ve } \\
\text { büyümesi }\end{array}$ \\
\hline
\end{tabular}

B.3.2. $\mathrm{Na}(+) / I(-)$ symporter (SLC5A5): Sodium iodide symporter (NIS) bir glikoprotein olup tiroid, tükrük bezi, mide ve meme dokusunda yüksek düzeylerde olmak üzere birçok dokuda aktif bir şekilde sentezlenir. Tiroid folliküler hücrelerinin bazolateral membranında bulunan NIS proteini iyot molekülünün hücre içine alınmasına aracılık eder. Tiroid stimülan hormon NIS ekspresyonunu artıran primer regülatör faktördür. Diğer regülatörleri ise $\mathrm{TGF} \beta, \mathrm{TNF} \alpha$, intörlökin $1 \alpha$ ve retinoik asittir. Birçok çalışma, tiroid kanserlerinde NIS ekspresyonunun düştügünü ya da hiç olmadığını bildirmektedir [49]. Tiroid kanser hücre differensiasyon düzeyi azaldıkça, NIS ekspresyonu daha da azalmakta hatta undiferensiye tiroid kanserlerinde hiç eksprese edilmemektedir. Hatta NIS ekspresyonundaki bu düşüşün tiroid hücre transformasyonunda en erken tetikleyici olduğu iddia edilmektedir [50,51]. NIS geni sadece tiroid kanserlerinin değil bütün tiroid hastalıklarının açıklanmasında önemli bir faktördür. 
B.3.3.Thyroid transcription factor-1 (TTF-1): TTF-1, tiroglobulin ve tiroperoksidaz genlerinin tiroid spesifik transkripsiyon promotoru olan bir proteindir [52]. TTF-1 tiroid dokusunun erken diferansiasyon ve morfogenezinde rol oynar. Papiller tiroid kanserinde $\% 96$, follikülerde $\% 100$, oxifilikte $20 \%$, medüllerde $90 \%$ oranında pozitif olduğu bildirilmektedir [53].

B.3.4. MTHFR (5,10-Methylene tetrahydrofolate reductase): MTHFR geni 5,10-metilen tetrahidrofolat redüktaz enzimini sentezleyen ve folat metabolizması üzerine etkili sistemik bir gendir. MTHFR enzimi, homosisteinin-metionin döngüsünde görev alır. Ayrıca DNA metilasyonu için tek metil kaynağı sağlayıcıdır. Yapılan çalışmalarda heterozigot/homozigot C677T mutant bireylerde MTHFR enzim aktivitesi \%30-65 oranında düştüğü bildirilmektedir. Şimdiye kadar kardiyovasküler hastalıklar ve homosistein metabolizma hastalıkları ile MTHFR enzim aktivitesi arasındaki ilişki net olarak ortaya konabilmişti [54]. Ancak son zamanlarda MTHFR'ın DNA metilasyonunda tek metil vericisi olması ve DNA metilasyonunda epigenetik düzenlemedeki önemli rolü nedeniyle kanserle olan ilişkiside araştırılmaya başlanmıştır. Hücrede metil vericisinin eksik olması durumunda metillenerek inaktive edilmesi gereken bazı genlerin, örneğin onkogenlerin metillenmemesi durumunda aktif hale gelerek onkogenik protein üretimiyle, hücrenin ilkin transfomasyonunda görev alabilirler. Birçok kanser tipiyle MTHFR gen mutasyonu arasındaki ilişkisi literatürde bildirilmektedir [55]. Nitekim bizde diferensiye tiroid kanserlerinde yaptığımız bir çalışmada MTHFR gen mutasyonu olan olgularda tiroid kanser riskinin yüksek olduğunu ve germ-line MTHFR mutabilitesinin önemli bir belirteç olabileceğini ortaya koyduk [56].

B.3.5. MDR1 (Multidrug Resistance 1): ATP binding cassete (ABCB1) gen ailesinden olan MDR1 geni, permeabilite-glikoprotein (P-gp) adında taşıyıc1 bir protein sentezlemektedir. P-gp bir transmembran protein olup çeşitli ksenobiyotikler, kimyasallar ve ilaçları hücrelerden uzaklaştırarak hücrede eflüx pompa görevi yapmaktadır. Bu protein ince ve kalın barsakta, pankreasta, böbrekte, karaciğerde, testiste ve kan beyin bariyerinde daha yoğun olmak üzere tüm dokularda bulunmaktadır. En yaygın mutasyon tipi MDR1 C3435T transisyonel silent mutasyondur [57]. Kemoterapiye dirençli tümör hücrelerinde aşırı sentezlendiği bilinmektedir. Son yayınlarda MDR1 gen mutasyonunun insanda birden fazla kanser tipiyle ilişkili olduğu rapor edilmektedir. Nitekim bizde MDR1 3435TT gen profilinin tiroid kanser riskini arttırdığını, iyi diferensiye tiroid kanser vakalarında yaptı̆̆ımız bir çalışmada bildirdik [58].

B.3.6. PAX8 (paired box 8): İnsan embriyonal dokularında primer olarak ekprese olan genden sentezlenen transkripsiyon faktörü tiroid ve böbrek dokusunun müllerian sistem gelişiminden sorumludur. Embriyonel dönemde maksimum düzeyde fonksiyon yapan gen yetişkin bireylerde promotor hipermetilasyonu ile inaktive edilmektedir. Mutasyon ya da epigenetik alterasyonlarla (promotor hipometilasyonu) yeniden aktif hale gelebilmekte ve sentezlediği transkripsiyon faktörüyle tiroid dokularında bölünmeyi tetikleyerek onkogeneze neden olabilmektedir. Tümör supresörler bölümünde bahsedildiği gibi $P P A R \gamma$ geniyle siklıkla rearrangement olarak da yeniden ekspresyon kazanabilmektedirler. Son yayınlarda papiller tiroid kanserlerinin \%5-10'unda, folliküler adenom ve kanserlerin \%30-40'1nda PAX8 gen ekspresyonu bildirilmiştir [29, 59, 60].

B.3.7. FOXE1 (forkhead box E1 (thyroid transcription factor 2)): FOXE1 bir transkripsiyon faktörü olup embriyonal dönemde over-eksprese olan gen tiroid primordium hücrelerinin ilkin farklılaşmasında, tiroid bezinin migrasyonunda ve gelişiminde PAX8 ile birlikte görev alır. Aynı zamanda FOXE1 geni PAX8 aktivasyonunda görev alan bir trankripsiyon faktörüdür. Yine $P A X 8$ geni gibi yetişkin bireylerde promotor bölge hipermetilasyonu yoluyla inaktive edilirler. Mutasyon ya da promotor hipometilasyonu ile yeniden aktif hale gelebilir. Gen bölgesinde meydana gelen yapısal mutasyonlar tiroid folliküler kanserde birlikte bildirimlikle birlikte sporadik ya da iyonize radyasyon nedenli papiller kanserlerde de bildirilmektedir. Funn ve arkadaşlarının Çin popülasyonuna iat papiller kanserlerde yaptığ 1 bir araştırmada FOXE1 genine ait 
tümör doku mRNA ekspresyonlarının sağlıklı dokuya oranla \%65 oranında daha yüksek olduğunu bildirmişlerdir. Yine aynı araştırıcılar FOXE1 mRNA düzeylerinin papiller tiroid kanserlerinin tanı ve tedavisinde önemli bir potansiyel biyomarkır olduğunu iddia etmektedirler [61,62].

B.4. MikroRNA (miRNA) downregülasyona bağlı tiroid kanserleri: MikroRNA'lar 1925 nükleotid uzunluğunda tek iplikli RNA molekülleridir ve ilk kez Lee ve çalışma arkadaşları tarafından 1993 yılında keşfedilmişlerdir. Protein sentezine katılmayan moleküller olup kendi nükleotid dizilerinin tamamlayıcısı olan hedef mRNA'lara bağlanıp translasyonel baskılama veya mRNA yıkımı ile transkripsiyon sonrası gen ekspresyonunun düzenlenmesini gerçekleştirirler. Kısaca miRNA'lar posttranskripsiyonal düzeyde gen düzenlemesinde görev alırlar. $\mathrm{Bu}$ görevleriyle hücre proliferasyonu, hücre farklılaşması, immün yanıt, hematopoezis ve apoptozis gibi homeostatik süreçlerde temel mediatör rol oynarlar [63, 64]. Ökaryatik hücrelerin normal fonksiyonlarının devamında rolü olan miRNA seviyelerinin normal koşulların dışına çıkmasının kanser dahil olmak üzere çeşitli hastalıklara neden olmaktadır. Farklı 100 geni regüle ettiği saptanmıştır. MiRNA'lar onkogenezin farklı basamaklarında bazı onkogen, tümör supresör ve fonksiyonel genlerin up/down regülasyonlarına aracılık ederler. MiRNA'lar tümör dokularına özgü tip ve miktarda sentezlenmektedir. Yapılan çalışmalar göstermiştir ki, kontrolsüz hücre bölünmesinin gerçekleştiği kanser hücrelerinde değişikliğe uğramış miRNA ekspresyonları söz konusudur. İnsan genomunda şimdiye kadar 1048 adet miRNA tanımlanmış olmakla birlikte kanserle ilişkili 22 tip miRNA bildirilmiştir. Örneğin mRNA-200 ailesinin epitelyal mezengimal transisyonda görev aldıkları ve kanser invazyonuyla ilgili oldukları bildirilmiştir $[63,65]$.

Son yıllarda yapılan çalışmalarda bazı tiroid kanser tiplerine özgü miRNA profilleri bildirilmektedir. miRNA-146b, 200, 221 ve 222'nin agresif papiller tiroid kanserinde over eksprese edildikleri gösterilmiştir [66]. Çeşitli kanser tiplerine özgüllük gösteren miRNA'ların analizi tanı tedavi ve prognozda miRNA'lar kanser tiplerine özgüllük gösterdiğinden tiroid kanser tanı, tedavi ve prognozun belirlenmesinde tanımlanması gereken moleküllerdir. Gerek TİIAB materyalinde miRNA bakılması gerek kandan miRNA bakılması erken tanı için önem arzetmektedir. Özellikle miRNA-200 ailesi tiroid kanserlerinin, subtiplemesinde ve yeni jenerasyon tedavi strategilerinde hedef molekül olarak görünmektedir. Tüm bu nedenlerden, miRNA'ların gelecekte kanserin erken teşhisi- tedavisi için önemli olacağı çok açıktır [67].

\section{Büyümeyi stimüle ve inhibe edici belirteçler}

Hücre büyümesini indükleyen ya da inhibe eden faktörlerdeki dengesizlikler kontrolsüz hücre proliferasyonuna ve transformasyonuna neden olabilirler.

\section{C.1. Büyümeyi stimüle edici faktörler}

C1.1. Epidermal growth faktör (EGF): EGF bir potent mitojen ve antidifferentiation ajanı olarak kabul edilir. EGF tiroglobulin, tiroid peroksidaz, Na-I symporter, TSHR ve cadherin sentezlerini inhibe etmektedirler. EGF'nin upregülasyonu folliküler tiroid kanserinden ziyade papiller tiroid kanserlerinde daha sik bildirilmektedir. EGF'nin upregülasyonu aynı zamanda tiroid kanser hücrelerinin invazyonunda etkilidirler [68, 69].

C.1.2. Transforming growth faktör $\boldsymbol{\alpha}(\boldsymbol{T G F} \alpha)$ : EGF'e benzer yapıda ve etkide olan TGF $\alpha$ potent mitojen olarak kabul edilmektedir. Papiller ve anaplastik karsinomlarda yüksek düzeyde eksprese edildiği bildirilmekle birlikte, normal tiroid hücrelerinde, multinodüler guatrda ve folliküler adenomda da yüksek düzeyde ekspresyonu sözkonusudur $[68,70]$.

C.1.3. Vascular endotelial growth faktör (VEGF): VEGF ve VEGF reseptörü angiogeneziste oldukça etkili bir parametredir. Papiller ve folliküler kanserlerinde VEGF ve reseptörlerinde artışlar bildirilmektedir. Solid tümörler 2-3mm çapa ulaştığında kendi beslenmelerini sağlayacak damarlanmaya (neovaskülarizasyon) ihtiyaç duyarlar. Yüksek 
oranda VEGF ekspresyonu saptanan tümörlerin metastatik potansiyelleri yüksek kabul edildiğinden, VEGF metastatik ve non-metastatik tümörlerin ayırımında önemli bir markır olarak kullanılabilir [71].

C.1.4. Insülin ve insülin like growth faktör 1 (IGF-1): Normal tiroid dokularında eksprese edilir ve tiroid hücre proliferasyonunda güçlü bir uyarıcı olduğu gösterilmiştir. Tiroid adenomlarında ve kanserlerinde normal dokuya göre daha fazla eksprese olduğu bildirilmektedir. Tümör büyüklüğü ve agresifliği ile insülin like growth faktör arasındaki ilişki hakkında ise çelişkili bilgiler bulunmaktadır [72].

\section{C.2. Büyümeyi inhibe edici faktörler}

C.2.1.Transforming growth faktör $\beta$ (TGFß): Epitelial hücre proliferasyonunda potent bir inhibitördür. TGF $\beta$ reseptör aktivasyonu cAMP bağımlı tirosit proliferasyonunu selektif olarak inhibe ederek apopitozisi indükler. Papiller tiroid kanserlerinde TGF reseptör mRNA seviyesinin anlamlı düzeyde düştüğü bildirilmektedir. Yine TGF reseptör mRNA seviyesi ile tümör çapı arasında indirekt bir ilişki raporlanmıştır [73].

C.2.2.Somastatin: Tiroid dokuları somastatin reseptörü içerirler ve bu hormonun uygulanması tiroid hücre proliferasyonunu inhibe eder. Tiroid tümörlerinde somastatin mRNA reseptör varyantları bildirilmektedir [74, 75].

Sonuç olarak; en sık görülen endokrin bez kanseri olan tiroid doku kanserlerinin tetiklenmesi ve ilerlemesi, nokta mutasyonlar, translokasyonlar, kromozomlar-arasi yeniden düzenlemeler, aktif proto-onkogen ve inaktif tümör baskılayıcı gen şeklinde meydana gelen epigenetik alterasyonlar gibi çoklu genetik ve epigenetik değişikliklerle gerçekleşmektedir. Son literatür bilgileri, tümör doku kimliklendirilmesinde sadece patolojik tiplemenin ve immünohistokimyasal belirteçlerin kullanılmasının yetersiz kaldığını açıklıkla ortaya koymaktadır. $\mathrm{Bu}$ nedenle tiroid nodül ve tümörlerinin olabildiğince moleküler genetik belirteçler açısından kimliklendirilmesinin kesin tanı ve etkin tedavi için hayati öneme sahiptir. Ancak bu durumda kanser subtiplemesi doğru yapılabilir ve bu doğrultuda hastanın doğru ve etkin tedavi alması sağlanabilir. İlgili nodül ve tümör dokusunun neden kanserleştiğinin ipuçlarını yine içinde barındırmaktadır, bu moleküler etyolojik sebeplerinin doğru tespiti tiroid kanserlerinin tedavisi için yeni ve etkin tedavi stratejilerinin geliştirilmesine olanak sağlayacaktır.

\section{Kaynaklar}

1. Pellegriti G, Frasca F, Regalbuto C, Squatrito S, Vigneri R. Worldwide increasing incidence of thyroid cancer: update on epidemiology and risk factors. $\mathrm{J}$ Cancer Epidemiol 2013; 2013: 965212.

2. Morris LG, Sikora AG, Tosteson TD, Davies L. The increasing incidence of thyroid cancer: the influence of access to care. Thyroid 2013; 23: 885-91.

3. Boufraqech M, Patel D, Xiong Y, Kebebew E. Diagnosis of thyroid cancer: state of art. Expert Opin Med Diagn 2013; 7: 331-42.

4. Zimmerman D. Thyroid carcinoma in children and adolescents: diagnostic implications of analysis of the tumor genome. Curr Opin Pediatr 2013; 25: 52831.

5. Kleinau G, Neumann S, Grüters A, Krude H, Biebermann H. Novel insights on thyroid-stimulating hormone receptor signal transduction. Endocr Rev 2013; 34: 691-724.

6. Fay DS. Cancer metabolism: feeding a worm to starve a tumor. Curr Biol 2013; 23: R557-9.

7. Nagayama Y. Thyroid cancer. Nihon Rinsho 2012; 70: 436-40.

8. Dvorkin S, Robenshtok E, Hirsch D, Strenov Y, Shimon I, Benbassat CA. Differentiated thyroid cancer is associated with less aggressive disease and better outcome in patients with coexisting hashimotos thyroiditis. J Clin Endocrinol Metab 2013; 98: 2409-14. 
9. Nagarkatti SS, Faquin WC, Lubitz CC, Garcia DM, Barbesino G, Ross DS, Hodin RA, Daniels GH, Parangi S. Management of thyroid nodules with atypical cytology on fine-needle aspiration biopsy. Ann Surg Oncol 2013; 20: 60-5.

10. Figlioli G, Landi S, Romei C, Elisei R, Gemignani F. Medullary thyroid carcinoma (MTC) and RET proto-oncogene: mutation spectrum in the familial cases and a meta-analysis of studies on the sporadic form. Mutat Res 2013; 752: 36-44.

11. Makki FM, Taylor SM, Shahnavaz A, Leslie A, Gallant J, Douglas S, Teh E, Trites J, Bullock M, Inglis K, Pinto DM, Hart RD. Serum biomarkers of papillary thyroid cancer. J Otolaryngol Head Neck Surg 2013; 42: 16.

12. Papale F, Cafiero G, Grimaldi A, Marino G, Rosso F, Mian C, Barollo S, Pennelli G, Sorrenti S, De Antoni E, Barbarisi A. Galectin-3 expression in thyroid fine needle cytology (t-FNAC) uncertain cases: Validation of molecular markers and technology innovation. J Cell Physiol 2013; 228: 968-74.

13. Cui W, Sang W, Zheng S, Ma Y, Liu X, Zhang W. Usefulness of cytokeratin-19, galectin-3, and Hector Battifora mesothelial-1 in the diagnosis of benign and malignant thyroid nodules. Clin Lab 2012; 58: 673-80.

14. Rossi ED, Straccia P, Palumbo M, Stigliano E, Revelli L, Lombardi CP, Santeusanio G, Pontecorvi A, Fadda G. Diagnostic and prognostic role of HBME-1, galectin-3, and $\beta$-catenin in poorly differentiated and anaplastic thyroid carcinomas. Appl Immunohistochem Mol Morphol 2013; 21: 237-41.

15. Griffith OL, Chiu CG, Gown AM, Jones SJ, Wiseman SM.Biomarker panel diagnosis of thyroid cancer: a critical review. Expert Rev Anticancer Ther 2008; 8: 1399-413.

16. Cochand-Priollet B, Dahan H, Laloi-Michelin M, Polivka M, Saada M, Herman P, Guillausseau PJ, Hamzi L, Poté N, Sarfati E, Wassef M, Combe H, RaulicRaimond D, Chedin P, Medeau V, Casanova D, Kania R. Immunocytochemistry with cytokeratin 19 and anti-human mesothelial cell antibody (HBME1) increases the diagnostic accuracy of thyroid fine-needle aspirations: preliminary report of 150 liquid-based fine-needle aspirations with histological control. Thyroid 2011; 21: 1067-73.

17. Rosário PW, Penna GC, Brandão K, Souza BÉ. Usefulness of preoperative serum calcitonin in patients with nodular thyroid disease without suspicious history or cytology for medullary thyroid carcinoma. Arq Bras Endocrinol Metabol 2013; 57: 312-6.

18. Duntas LH. Clinical comments related to medullary thyroid cancer diagnosis and management. Thyroid Res 2013; 6 Suppl 1:S6.

19. Taccaliti A, Boscaro M. Genetic mutations in thyroid carcinoma. Minerva Endocrinol 2009; 34: 11-28.

20. Fusco A, Grieco M, Santoro M, Berlingieri MT, Pilotti S, Pierotti MA, Della Porta G, Vecchio G. A new oncogene in human thyroid papillary carcinomas and their lymph-nodal metastases. Nature 1987; 328: 170-2.

21. Vander Poorten V, Hens G, Delaere P. Thyroid cancer in children and adolescents. Curr Opin Otolaryngol Head Neck Surg 2013; 21: 135-42.

22. Li C, Lee KC, Schneider EB, Zeiger MA. BRAF V600E mutation and its association with clinicopathological features of papillary thyroid cancer: a metaanalysis. J Clin Endocrinol Metab 2012; 97: 4559-70.

23. Fernandez IJ, Piccin O, Sciascia S, Cavicchi O, Repaci A, Vicennati V, Fiorentino M. Clinical significance of $B R A F$ mutation in thyroid papillary cancer. Otolaryngol Head Neck Surg 2013; 148: 919-25.

24. Ward LS, Kloos RT. Molecular markers in the diagnosis of thyroid nodules. Arq Bras Endocrinol Metabol 2013; 57: 89-97.

25. Cappola AR, Mandel SJ. Molecular testing in thyroid cancer: BRAF mutation status and mortality. JAMA 2013; 309: 1529-30. 
26. Rosove MH, Peddi PF, Glaspy JA. BRAF V600E inhibition in anaplastic thyroid cancer. N Engl J Med 2013; 368: 684-5.

27. Park SJ, Sun JY, Hong K, Kwak JY, Kim EK, Chung WY, Choi JR. Application of $B R A F, N R A S, K R A S$ mutations as markers for the detection of papillary thyroid cancer from FNAB specimens by pyrosequencing analysis. Clin Chem Lab Med 2013; 51: 1673-80.

28. Grande E, Díez JJ, Zafon C, Capdevila J. Thyroid cancer: molecular aspects and new therapeutic strategies. J Thyroid Res 2012; 2012: 847108.

29. Patel KN, Singh B. Genetic considerations in thyroid cancer. Cancer Control 2006; 13: 111-8.

30. Fagin JA, Mitsiades N. Molecular pathology of thyroid cancer: diagnostic and clinical implications. Best Pract Res Clin Endocrinol Metab 2008; 22: 955-69.

31. Ferreira CV, Siqueira DR, Ceolin L, Maia AL. Advanced medullary thyroid cancer: pathophysiology and management. Cancer Manag Res 2013; 5: 57-66.

32. Wagner SM, Zhu S, Nicolescu AC, Mulligan LM. Molecular mechanisms of RET receptor-mediated oncogenesis in multiple endocrine neoplasia 2. Clinics (Sao Paulo) 2012; 67: 77-84.

33. Weier HU, Ito Y, Kwan J, Smida J, Weier JF, Hieber L, Lu CM, Lehmann L, Wang M, Kassabian HJ, Zeng H, O'Brien B. Delineating Chromosomal Breakpoints in Radiation-Induced Papillary Thyroid Cancer. Genes (Basel) 2011; 2: 397-419.

34. Hamatani K, Eguchi H, Ito R, Mukai M, Takahashi K, Taga M, Imai K, Cologne J, Soda M, Arihiro K, Fujihara M, Abe K, Hayashi T, Nakashima M, Sekine I, Yasui W, Hayashi Y, Nakachi K. RET/PTC rearrangements preferentially occurred in papillary thyroid cancer among atomic bomb survivors exposed to high radiation dose. Cancer Res 2008; 68: 7176-82.

35. de Vries MM, Celestino R, Castro P, Eloy C, Máximo V, van der Wal JE, Plukker JT, Links TP, Hofstra RM, Sobrinho-Simões M, Soares P. RET/PTC rearrangement is prevalent in follicular Hürthle cell carcinomas. Histopathology 2012; 61: 833-43.

36. Mathur A, Weng J, Moses W, Steinberg SM, Rahbari R, Kitano M, Khanafshar E, Ljung BM, Duh QY, Clark OH, Kebebew E. A prospective study evaluating the accuracy of using combined clinical factors and candidate diagnostic markers to refine the accuracy of thyroid fine needle aspiration biopsy. Surgery 2010; 148: 1170-6.

37. Soares P, Lima J, Preto A, Castro P, Vinagre J, Celestino R, Couto JP, Prazeres H, Eloy C, Máximo V, Sobrinho-Simões M. Genetic alterations in poorly differentiated and undifferentiated thyroid carcinomas. Curr Genomics 2011; 12: 609-17.

38. Bu R, Uddin S, Ahmed M, Hussain AR, Alsobhi S, Amin T, Al-Nuaim A, AlDayel F, Abubaker J, Bavi P, Al-Kuraya KS. c-Met inhibitor synergizes with tumor necrosis factor-related apoptosis-induced ligand to induce papillary thyroid carcinoma cell death. Mol Med 2012; 18: 167-77.

39. Miyake Y, Aratake Y, Sakaguchi T, Kiyoya K, Kuribayashi T, Marutsuka K, Ohno E. Examination of CD26/DPPIV, p53, and PTEN expression in thyroid follicular adenoma. Diagn Cytopathol 2012; 40: 1047-53.

40. Santoro A, Pannone G, Carosi MA, Francesconi A, Pescarmona E, Russo GM, Feola A, Losito S, Franco R, Nappi L, Aquino G, De Rosa G, Di Domenico M, Bufo P. BRAF mutation and RASSF1A expression in thyroid carcinoma of southern Italy. J Cell Biochem 2013; 114: 1174-82.

41. Kajabova V, Smolkova B, Zmetakova I, Sebova K, Krivulcik T, Bella V, Kajo K, Machalekova K, Fridrichova I. RASSF1A Promoter Methylation Levels Positively Correlate with Estrogen Receptor Expression in Breast Cancer Patients. Transl Oncol 2013; 6: 297-304. 
42. Brait M, Loyo M, Rosenbaum E, Ostrow KL, Markova A, Papagerakis S, Zahurak M, Goodman SM, Zeiger M, Sidransky D, Umbricht CB, Hoque MO. Correlation between $B R A F$ mutation and promoter methylation of TIMP3, RAR $\beta 2$ and RASSF1A in thyroid cancer. Epigenetics 2012; 7: 710-9.

43. Koenig RJ. Detection of the PAX8-PPARgamma fusion protein in thyroid tumors. Clin Chem 2010; 56: 331-3.

44. Eberhardt NL, Grebe SK, McIver B, Reddi HV. The role of the PAX8/PPARgamma fusion oncogene in the pathogenesis of follicular thyroid cancer. Mol Cell Endocrinol 2010; 321: 50-6.

45. Lee YM, Lee JB. Prognostic value of epidermal growth factor receptor, p53 and galectin-3 expression in papillary thyroid carcinoma. Int Med Res 2013; 41: 82534.

46. Yilike X, Kuerban G, Yang X, Wu S, Abudula A. Expression of MGMT and its clinopathological significance in thyroid carcinoma. Zhong Nan Da Xue Xue Bao Yi Xue Ban 2010; 35: 1219-24.

47. Liotti F, Visciano C, Melillo RM. Inflammation in thyroid oncogenesis. Am J Cancer Res 2012; 2: 286-97.

48. Kim WG, Zhu X, Kim DW, Zhang L, Kebebew E, Cheng SY. Reactivation of the silenced thyroid hormone receptor $\beta$ gene expression delays thyroid tumor progression. Endocrinology 2013; 154: 25-35.

49. Lavarone E, Puppin C, Passon N, Filetti S, Russo D, Damante G. The PARP inhibitor PJ34 modifies proliferation, NIS expression and epigenetic marks in thyroid cancer cell lines. Mol Cell Endocrinol 2013; 365: 1-10.

50. Kouniavsky G, Zeiger MA. Thyroid tumorigenesis and molecular markers in thyroid cancer. Curr Opin Oncol 2010; 22: 23-9.

51. Wang S, Liang J, Lin Y, Yao R. Differential expression of the $\mathrm{Na}(+) / \mathrm{I}(-)$ symporter protein in thyroid cancer and adjacent normal and nodular goiter tissues. Oncol Lett 2013; 5: 368-72.

52. Kondo T, Nakazawa T, Ma D, Niu D, Mochizuki K, Kawasaki T, Nakamura N, Yamane T, Kobayashi M, Katoh R. Epigenetic silencing of TTF-1/NKX2-1 through DNA hypermethylation and histone $\mathrm{H} 3$ modulation in thyroid carcinomas. Lab Invest 2009; 89: 791-9.

53. Montanelli L, Tonacchera M. Genetics and phenomics of hypothyroidism and thyroid dys- and agenesis due to PAX8 and TTF1 mutations. Mol Cell Endocrinol 2010; 322: 64-71.

54. Fard-Esfahani P, Fard-Esfahani A, Saidi P, Fayaz S, Mohabati R, Majdi M. An increased risk of differentiated thyroid carcinoma in Iran with the $677 \mathrm{C} \rightarrow \mathrm{T}$ homozygous polymorphism in the MTHFR Gene. Cancer Epidemiol 2011; 35: 56-8.

55. Prasad VV, Wilkhoo H. Association of the functional polymorphism C677T in the methylenetetrahydrofolate reductase gene with colorectal, thyroid, breast, ovarian, and cervical cancers. Onkologie 2011; 34: 422-6.

56. Özdemir S, Silan F, Hasbek Z, Uludağ A, Atik S, Erselcan T, Özdemir Ö. Increased T-allele frequency of $677 \mathrm{C}>\mathrm{T}$ polymorphism in the methylenetetrahydrofolate reductase gene in differentiated thyroid carcinoma. Genet Test Mol Biomarkers 2012; 16: 780-4.

57. Huang L, Perrault C, Coelho-Martins J, Hu C, Dulong C, Varna M, Liu J, Jin J, Soria C, Cazin L, Janin A, Li H, Varin R, Lu H. Induction of acquired drug resistance in endothelial cells and its involvement in anticancer therapy. $\mathrm{J}$ Hematol Oncol 2013; 6: 49.

58. Özdemir S, Uludağ A, Silan F, Atik SY, Turgut B, Özdemir Ö. Possible Roles of the Xenobiotic Transporter P-glycoproteins Encoded by the MDR1 3435 C>T Gene Polymorphism in Differentiated Thyroid Cancers. Asian Pac J Cancer Prev 2013; 14: 3213-7. 
59. Pasca di Magliano M, Di Lauro R, Zannini M. Pax 8 has a key role in thyroid cell differentiation. Proc Natl Acad Sci U S A 2000; 97: 13144-9.

60. Ruiz-Llorente S, Carrillo Santa de Pau E, Sastre-Perona A, Montero-Conde C, Gómez-López G, Fagin JA, Valencia A, Pisano DG, Santisteban P. Genome-wide analysis of Pax 8 binding provides new insights into thyroid functions. BMC Genomics 2012; 13: 147.

61. Fan Y, Ding Z, Yang Z, Deng X, Kang J, Wu B, Zheng Q. Expression and clinical significance of FOXE1 in papillary thyroid carcinoma. Mol Med Rep 2013; 8: 123-7.

62. Bychkov A, Saenko V, Nakashima M, Mitsutake N, Rogounovitch T, Nikitski A, Orim F, Yamashita S. Patterns of FOXE1 Expression in Papillary Thyroid Carcinoma by Immunohistochemistry. Thyroid 2013; 23: 817-28.

63. de la Chapelle A, Jazdzewski K. MicroRNAs in thyroid cancer. J Clin Endocrinol Metab 2011; 96: 3326-36.

64. Sun Y, Yu S, Liu Y, Wang F, Liu Y, Xiao H. Expression of miRNAs in Papillary Thyroid Carcinomas Is Associated with BRAF Mutation and Clinicopathological Features in Chinese Patients. Int J Endocrinol 2013; 2013: 128735.

65. Zhang X, Li M, Zuo K, Li D, Ye M, Ding L, Cai H, Fu D, Fan Y, Lv Z. Upregulated miR-155 in papillary thyroid carcinoma promotes tumor growth by targeting APC and activating Wnt/ $\beta$-catenin signaling. J Clin Endocrinol Metab. 2013; 98: E1305-13.

66. Zhang J, Liu Y, Liu Z, Wang XM, Yin DT, Zheng LL, Zhang DY, Lu XB. Differential expression profiling and functional analysis of microRNAs through stage I-III papillary thyroid carcinoma. Int J Med Sci 2013; 10: 585-92.

67. Li X, Abdel-Mageed AB, Mondal D, Kandil E. MicroRNA expression profiles in differentiated thyroid cancer, a review. Int J Clin Exp Med 2013; 6: 74-80.

68. Mincione G, Di Marcantonio MC, Tarantelli C, D'Inzeo S, Nicolussi A, Nardi F, Donini CF, Coppa A. EGF and TGF- $\beta 1$ Effects on Thyroid Function. J Thyroid Res 2011; 2011: 431718.

69. Hoffmann S, Burchert A, Wunderlich A, Wang Y, Lingelbach S, Hofbauer LC, Rothmund M, Zielke A. Differential effects of cetuximab and AEE 788 on epidermal growth factor receptor (EGF-R) and vascular endothelial growth factor receptor (VEGF-R) in thyroid cancer cell lines. Endocrine 2007; 31: 105-13.

70. Lam AK, Lau KK, Gopalan V, Luk J, Lo CY. Quantitative analysis of the expression of TGF-alpha and EGFR in papillary thyroid carcinoma: clinicopathological relevance. Pathology 2011; 43: 40-7.

71. Karaca Z, Tanrıverdi F, Unluhızarcı K, Öztürk F, Gökahmetoğlu S, Elbüken G, Çakır I, Bayram F, Kelestimur F. VEGFR1 expression is related to lymph node metastasis and serum VEGF may be a marker of progression in the follow-up of patients with differentiated thyroid carcinoma. Eur J Endocrinol 2011; 164: 277 84.

72. Haisa M. The type 1 insulin-like growth factor receptor signalling system and targeted tyrosine kinase inhibition in cancer. J Int Med Res 2013; 41: 253-64.

73. Eloy C, Santos J, Cameselle-Teijeiro J, Soares P, Sobrinho-Simões M. TGFbeta/Smad pathway and BRAF mutation play different roles in circumscribed and infiltrative papillary thyroid carcinoma. Virchows Arch 2012; 460: 587-600.

74. Pazaitou-Panayiotou K, Tiensuu Janson E, Koletsa T, Kotoula V, Stridsberg M, Karkavelas G, Karayannopoulou G. Somatostatin receptor expression in nonmedullary thyroid carcinomas. Hormones (Athens) 2012; 11: 290-6.

75. Treglia G, Rindi G, Rufini V. Expression of somatostatin receptors may guide the use of somatostatin receptor imaging and therapy in differentiated thyroid cancer. Hormones (Athens) 2012; 11: 230-2. 